Nicole Suclla Fernández

Gestão de múltiplos projetos por meio da metodologia da cadeia crítica: Efeitos do buffer de capacidade e dos critérios para priorizar atividades

Dissertação de Mestrado

Dissertação apresentada como requisito parcial para obtenção de grau de mestre pelo Programa de PósGraduação em Engenharia de Produção do Departamento de Engenharia Industrial da PUC-Rio.

Orientador: Prof. Leonardo Junqueira Lustosa

Rio de Janeiro Maio 2008 
Nicole Suclla Fernández

\section{Gestão de múltiplos projetos por meio da metodologia da cadeia crítica: Efeitos do buffer de capacidade e dos critérios para priorizar atividades}

Dissertação apresentada como requisito parcial para obtenção de grau de mestre pelo Programa de PósGraduação em Engenharia de Produção do Departamento de Engenharia Industrial da PUC - Rio. Aprovada pela Comissão Examinadora abaixo assinada.

Prof. Leonardo Junqueira Lustosa Orientador Departamento de Engenharia Industrial - PUC - Rio

Prof. Nélio Domingues Pizzolato Departamento de Engenharia Industrial - PUC - Rio

Prof. Silvio Hamacher Departamento de Engenharia Industrial - PUC - Rio

Prof. José Eugênio Leal Coordenador Setorial do Centro Técnico Cientifico - PUC - Rio

Rio de Janeiro, 16 de maio de 2008 
Todos os direitos reservados. É proibida a reprodução total ou parcial do trabalho sem autorização da universidade, do autor e do orientador.

\section{Nicole Suclla Fernández}

Graduou-se em Engenharia Industrial na "Universidad Nacional de San Agustín”, Arequipa - Perú em fev., 2004. Obteve o Premio de Excelência Universitária outorgado anualmente pela associação “AFP Unión Vida”. Realizou cursos de extensão em Gestão de serviços, Qualidade total, Gestão de recursos humanos e Programação de PLC I de Allen Bradley. Estagiou como assistente técnico-gerencial de microempresários na ONG Cecycap e na área de controle da produção na mineradora "Sociedade Minera Cerro Verde SAA". Trabalhou na área de Logística e controle de custos durante o 2004 - 2005.

Ficha Catalográfica

Fernández, Nicole Suclla

Gestão de múltiplos projetos por meio da metodologia da cadeia crítica: efeitos do buffer de capacidade e dos critérios para priorizar atividades / Nicole Suclla Fernández; orientador: Leonardo Junqueira Lustosa. -2008.

137 f. : il.(col.) ; $30 \mathrm{~cm}$

Dissertação (Mestrado em Engenharia Industrial)-Pontifícia Universidade Católica do Rio de Janeiro, Rio de Janeiro, 2008.

Inclui bibliografia

1. Engenharia Industrial - Teses. 2. Múltiplos projetos. 3. Cadeia crítica. 4. Buffer de capacidade. 5. Gestão de projetos. 6. Critérios para priorizar atividades. I. Lustosa, Leonardo Junqueira. II. Pontifícia Universidade Católica do Rio de Janeiro. Departamento de Engenharia Industrial. V. Título. 
Para meus pais, que me apoiaram incondicionalmente, confiando sempre na minha capacidade e me mostrando a luz no final do caminho. Para VOCÊ que sempre me guias pelo caminho certo, mesmo quando eu esqueço que estas comigo. 


\section{Agradecimentos}

Ao meu orientador Prof. Leonardo Lustosa, por compartilhar comigo seus conhecimentos e sua experiência, fazendo da orientação um relacionamento de amigos e colaboradores.

Aos integrantes da banca examinadora pela disponibilidade e observações importantes que realçaram este trabalho

Ao Luiz Cesar Nanci pelas observações relevantes que me ajudaram a esclarecer os objetivos finais deste trabalho

Aos meus amigos pelas dicas de pesquisa e estudo que facilitaram o desenvolvimento deste trabalho

Aos meus pais, pela transmissão de experiências e conselhos oportunos que não só me ajudaram na pesquisa, senão também para o dia-a-dia.

A Paula e ao Leandro por estar sempre comigo e "limpar minha cabeça" quando as preocupações me invadiam.

A minha família pela motivação para ser sempre melhor

A Capes pela bolsa de estudos que me permitiu iniciar o caminho da pesquisa e culminar este trabalho.

A Prochain Solutions Inc. pela disponibilidade de licenças.

Sem a participação de vocês não estaria aqui e este trabalho não existiria. 


\section{Resumo}

Fernández, Nicole Suclla; Lustosa, Leonardo Junqueira; Gestão de múltiplos projetos por meio da metodologia da cadeia crítica: Efeitos do buffer de capacidade e dos critérios para priorizar atividades. Rio de Janeiro, 2008. 137p. Dissertação de Mestrado - Departamento de Engenharia Industrial, Pontifícia Universidade Católica do Rio de Janeiro.

Este trabalho trata da gestão de múltiplos projetos mediante a metodologia da Cadeia Crítica e Gestão de Buffers (Critical Chain and Buffer Management $\mathrm{CC} / \mathrm{BM})$. Concentra-se na análise e entendimento dos efeitos que as abordagens mais usuais para dimensionamento dos buffers de capacidade (Capacity Buffers BC) e definição dos critérios de priorização de atividades têm sobre os objetivos da empresa e dos próprios projetos. O estudo baseia-se num problema-exemplo apresentado por Pritsker B. et al. (1969.). Para facilitar a análise, esse exemplo se caracteriza por uma estrutura simples, mas que apresenta interdependências relevantes para o estudo dos conflitos de compartilhamento de recursos entre projetos. Analisam-se as abordagens de "todos juntos”, "projetos sucessivos" e do “recurso gargalo”, propostas por Newbold (1998) para planejamento conjunto de projetos simultâneos. Tais abordagens são implementadas através das ferramentas de programação de projetos Prochain \& Pipeline. A partir dos programas (schedules) resultantes, analisam-se as características e deficiências de cada abordagem. Ademais, tais resultados permitem identificar certas condições e efeitos conflitantes no dimensionamento dos BC e no critério de priorização de atividades utilizado nas implementações típicas da metodologia. Tais observações criaram a necessidade de complementar a análise mediante a simulação probabilística da etapa de execução dos projetos. A pesquisa explica a diferença entre os efeitos dos critérios de priorização dinâmica e estática, esclarece a interação entre os buffers de capacidade e buffers de projeto. Ela ainda analisa os efeitos de dimensionar os BCs, para todos os projetos, como uma mesma porcentagem da carga do recurso e ilustra os trade-offs entre estabilidade do sistema e o makespan dos projetos.

\section{Palavras-chaves}

Múltiplos projetos; cadeia crítica; buffer de capacidade; gestão de projetos; critérios para priorizar atividades 


\section{Abstract}

Fernández, Nicole Suclla; Lustosa, Leonardo Junqueira; Multi-project management through the critical chain methodology: Effects of capacity buffer and of the criteria to prioritize activities. Rio de Janeiro, 2008. 137p. Master Dissertation - Industrial Engineering Department, PUCRio

This research addresses the management of multiple simultaneous projects through the application of the Critical Chain and Buffers Management (CC/BM) methodology. The focus is on the analysis and interpretation of the effects that the more usual approaches for Capacity Buffers (CB) sizing and criteria to prioritize activities have on the company's and on the projects' own objectives. The study is based on the problem-example presented by Pritsker B. et al. (1969.) For simplifying the analysis, this example is characterized by a simple structure that, nevertheless, presents interdependences significant for the study of conflicts created by sharing resources between simultaneous projects. The approaches for simultaneous projects management, presented by Newbold (1998) are analyzed, namely: "the all together”, "the successive projects" and "the strategic resource”. Their implementations are made using the Prochain \& Pipeline multi-project management tools. From the resulting schedules, the characteristics and deficiencies of each approach are analyzed. Furthermore, these results allow the identification of certain conditions and conflicting effects in the BC sizing and in the criteria used to prioritize activities in the typical methodology implementations. Such observations led to the necessity of complementing the analysis with the aid of probabilistic simulation of the projects' execution stage. The research explains the differences between the effects of dynamic and static prioritization, elucidates the interaction between the capacity and the project buffers. It also examines the effects of using the same percentage of the resource load for sizing the BCs for all the projects, and illustrates the trade-offs between the system stability and the projects makespan.

\section{Keywords}

Multi-projects; critical chain; capacity buffer; project management; criteria to prioritize activities. 


\section{Sumario}

1 Introdução 17

$\begin{array}{ll}\text { 1.1. Motivação do estudo } & 17\end{array}$

1.2. Objetivo da pesquisa 22

1.2.1. As abordagens de aplicação da metodologia: 22

1.2.2. Os critérios de priorização de projetos: 23

1.2.3. O comportamento dos principais buffers de tempo 24

1.3. Delimitação do estudo 25

1.4. Relevância do estudo 26

1.5. Organização do texto 27

2 Contexto e literatura diretamente relacionada 28

2.1. A motivação da pesquisa dentro da literatura de gestão de projetos.

2.2. A aplicação da metodologia CC/BM em múltiplos projetos e o estudo da arte $\quad 30$

2.2.1. Estudos da gestão clássica de projetos individuais 30

2.2.2. A gestão de projetos individuais por meio da CC/BM 31

2.2.3. A gestão de múltiplos projetos por meio da CC/BM 35

3 Conceitos e base teórica

3.1. A metodologia da cadeia crítica e gestão de buffers de tempo (CC/BM) 38

3.1.1. Teoria das restrições - TOC (Theory of Constraints) 38

3.1.2. CC/BM em projetos individuais 40

3.1.3. CC/BM em múltiplos projetos 51

4 Metodologia da pesquisa - Efeito das abordagens 57

4.1. O problema-exemplo 58

4.1.1. O Problema original 58

4.1.2. Casos de estudos teóricos: Variação do problema original 60 
4.2. As abordagens de aplicação

4.2.1. Abordagem de "Todos juntos" 61

4.2.2. Abordagem de "Projetos sucessivos" 61

4.2.3. Abordagem do "Recurso estratégico ou gargalo" 62

4.3. Implementação dos casos de estudo 62

4.3.1. Abordagem de "Todos juntos" 63

4.3.2. Abordagem de "Projetos sucessivos" 68

4.3.3. Abordagem do "Recurso estratégico ou gargalo" 79

5 Efeitos do buffer de capacidade e da priorização de atividades 89

5.1. Efeitos dos buffers de capacidade - BC 89

5.1.1. Objetivos 89

5.1.2. Estrutura da Simulação 90

5.2. Efeitos da priorização de atividades. 98

5.2.1. Objetivos 98

5.2.2. Estrutura da simulação 98

5.3. Análise dos resultados 101

5.3.1. Efeitos dos BC 101

5.3.2. Efeitos dos critérios de priorização 113

$\begin{array}{ll}6 \text { Conclusões e sugestões } & 118\end{array}$

$\begin{array}{ll}7 \text { Bibliografia } & 123\end{array}$

8 Apêndice A: Prochain \& Pipeline 125

8.1. Parâmetros de programação 125

$\begin{array}{ll}\text { 8.2. Principais Indicadores } & 127\end{array}$

9 Apêndice B: Resultados da simulação 128

$\begin{array}{ll}\text { 9.1. Análise das causas de atrasos } & 128\end{array}$

9.2. Trade-off entre Makespan e diminuição de atrasos

$\begin{array}{ll}\text { por falta de recurso } & 131\end{array}$

9.3. Efeitos dos critérios de priorização 133 


\section{Lista de Figuras}

Figura 1.1: Condições de sucesso dos projetos

Figura 2.1: Classificação de projetos.

Figura 3.1: Distribuição de probabilidade das

durações das atividades

42

Figura 3.2: Execução de atividades com multi-tarefas (multitasking)

Figura 3.3: Execução de atividades sem multi-tarefas

Figura 3.4: Exemplo clássico de gerenciamento de buffers.

Figura 3.5: O Programa base e o programa projetado

Figura 3.6: Principais elementos da metodologia CC/BM

Figura 3.7: Principais elementos da metodologia CC/BM em múltiplos projetos.

Figura 4.2: Programa ótimo modificado

Figura 4.3: Representação gráfica das redes dos projetos.

Figura 4.4: Incongruência entre importância de atividades e definição da cadeia crítica. Status ao 9/10 
Figura 4.6:Atrasos nos projetos um e dois. Status ao dia 12/10

Figura 4.7 : Programa máster nivelando todos os recursos.

Status do dia 09/10

Figura 4.8: Reprogramando o máster. Status do 12/10

Figura 4.9: Sem reprogramar o máster. Status do 12/10

Figura 4.10: Programa projetado sugerido em base a

prioridades fixas. Status ao dia 15/10

Figura 4.11: Programa resultante da aplicação de prioridades dinâmicas. Status do dia 16/10

Figura 4.12: Programa máster segundo prioridades 1,3,2.

Status ao dia $9 / 10$

Figura 4.13: Programa master baseado no recurso gargalo "A".

Status do dia 8/10

Figura 4.14: Diagrama de carga de trabalho, Recurso "A"

(Programa sem BC)

Figura 4.15: Diagrama de carga de trabalho, Recurso "B" (Programa sem BC)

Figura 4.16: Diagrama de carga de trabalho, Recurso "C" (Programa sem BC)

Figura 4.17: Programa máster com BC ao 25\% .

Status do dia $8 / 10$

Figura 4.18: Diagrama de carga de trabalho, Recurso "B" (Programa com BC 25\%) 
Figura 4.19: Diagrama de carga de trabalho, Recurso "C" (Programa com BC 25\%)

Figura 4.20: Programa máster com BC 25\%.

Status do dia 17/10

Figura 4.21: Programa máster híbrido. Status do dia 09/10 (Programa projetado com BC 25\%)

Figura 5.1: Programa base do modelo de simulação

Figura 5.2: Distribuição Binomial negativa

Figura 5.3: Modelo de simulação dos efeitos do BC

Figura 5.4: Modelo de simulação dos efeitos do critério de priorização de atividades

101

Figura 5.5: Consumo de BP - 25\% prob. Atraso

103

Figura 5.6: Consumo de BP - 20\% prob. Atraso

Figura 5.7: Consumo de BP - 15\% prob. Atraso

Figura 5.8: Consumo de BP - 10\% prob. Atraso

Figura 5.9: Mitigação dos atrasos por falta de recurso (Projeto dois - $25 \%$ de probabilidade de atraso)

Figura 5.10: Mitigação dos atrasos por falta de recurso (Projeto três - 25\% de probabilidade de atraso)

Figura 5.11: Mitigação dos atrasos por falta de recurso (Projeto dois - $20 \%$ de probabilidade de atraso) 
Figura 5.12: Mitigação dos atrasos por falta de recurso

(Projeto três - 15\% de probabilidade de atraso)

Figura 5.13: Mitigação dos atrasos por falta de recurso (Projeto dois - 15\% de probabilidade de atraso)

Figura 5.14: Mitigação dos atrasos por falta de recurso (Projeto três - 15\% de probabilidade de atraso)

Figura 5.15: Mitigação dos atrasos por falta de recurso (Projeto dois - 10\% de probabilidade de atraso)

Figura 5.16: Mitigação dos atrasos por falta de recurso (Projeto três - $10 \%$ de probabilidade de atraso)

Figura 5.17: Trade-off entre makespan e redução de atrasos por falta de recurso (25\% probabilidade de atraso)

Figura 5.18: Trade-off entre makespan e redução de atrasos por falta de recurso (20\% probabilidade de atraso)

Figura 5.19: Trade-off entre makespan e redução de atrasos por falta de recurso (15\% probabilidade de atraso)

Figura 5.20: Trade-off entre makespan e redução de atrasos por falta de recurso (10\% probabilidade de atraso)

Figura 5.21: Caso especial dos efeitos do BC

Figura 5.22: Efeitos dos critérios da priorização no sistema

Figura 5.23 : Efeitos dos critérios da priorização no sistema

Figura 5.24 : Efeitos dos critérios da priorização no projeto 1 
Figura 5.25 : Efeitos dos critérios da priorização no projeto dois

Figura 5.26: Efeitos dos critérios da priorização no projeto três.

Figura 9.1: Atraso do projeto um - segunda parte

Figura 9.2: Atraso do projeto dois - segunda parte

136

Figura 9.3: Atraso do projeto dois - segunda parte 


\section{Lista de Tabelas}

Tabela 4.1: Dados das redes dos múltiplos projetos

Tabela 5.1: Descrição das variáveis que definem o programa de linha de base

Tabela 5.2: Descrição das variáveis que definem o programa projetado

Tabela 8.1: Parâmetros de programação de projetos individuais - Prochain

Tabela 8.2: Parâmetros de programação de múltiplos projetos - Pipeline

Tabela 8.3: Indicadores

Tabela 9.1: Componentes de consumo do BP - 25\% prob. Atraso

Tabela 9.2: Atraso efetivo dos projetos - 25:\% prob. de atraso

Tabela 9.3: Componentes de consumo do BP - 20\% prob. Atraso

Tabela 9.4: Atraso efetivo dos projetos - 20:\% prob. de atraso

Tabela 9.5: Componentes de consumo do BP - 15\% prob. Atraso 
Tabela 9.8: Atraso efetivo dos projetos - 10:\% prob. de atraso

Tabela 9.9: Trade-off (25\% prob. Atraso)

Tabela 9.10: Trade-off (20\% prob. Atraso)

131

Tabela 9.11: Trade-off (15\% prob. Atraso)

132

Tabela 9.12: Trade-off (10\% prob. Atraso)

132

Tabela 9.13: Atraso efetivo do projeto um 133

Tabela 9.14: Atraso efetivo do projeto dois 133

Tabela 9.15: Atraso efetivo do projeto três

134

Tabela 9.16: Atraso efetivo do sistema

134 